\title{
Regional 1D hydrocarbon maturation modelling of the Cenomanian-Turonian Lokpanta Shale, southern Benue Trough, Nigeria: Implications for the origin of Niger Delta deep sea oils
}

\author{
Johnson O Amobi ${ }^{1}$, Celestine O Okogbue ${ }^{1}$, Ayonma W Mode ${ }^{1, *}$, \\ Anthony E Ofoma ${ }^{2}$, Chidozie I P Dim ${ }^{1}$ and Ikenna C OKwara ${ }^{1}$ \\ ${ }^{1}$ Department of Geology, University of Nigeria, Nsukka, Enugu, Nigeria. \\ ${ }^{2}$ Halliburton Energy Services, Lagos, Nigeria. \\ *Corresponding author.e-mail: wilfred.mode@unn.edu.ng
}

MS received 18 May 2018; revised 28 December 2018; accepted 15 February 2019; published online 19 June 2019

Basin modelling, constrained by geochemical data from eight wells, was carried out, across the late Cretaceous and Early Palaeogene sediment packages of south-eastern Nigeria sedimentary basins. The study was aimed at establishing the sediment burial history, thermal maturation of the source rock and timing of hydrocarbon generation. The Late Cenomanian to Early Turonian Lokpanta Shale, which is the basal unit of the Eze-Aku Formation in the Eze-Aku Group, consists of alternating dark grey to black shales, marl and siltstones. The upper sections are mainly alternating sandstones, shales and limestones. This unit is the key petroleum source rock for the basin. Numerical 1D basin model of the study area revealed that the Cenomanian to Turonian times was the main phase of rifting in the Benue Trough evidenced by rapid subsidence. Subsidence rates varied widely in all the wells studied, ranging from 29-61 m/Mya (million years ago) and averaging $44 \mathrm{~m} /$ Mya. Subsidence rates also varied widely through geological time from the Cretaceous to the Palaeogene. The Cenomanian-Turonian and the Maastrichtian ages recorded the highest subsidence rates (169.75 and $168.28 \mathrm{~m} /$ Mya, respectively). These phases of rapid subsidence correspond to the main phase of rifting (Cenomanian-Turonian) and periods of increased sediment supply (Campanian and Maastrichtian), due to rapid erosion and unroofing of the structurally inverted Benue Trough, post-Santonian. Vitrinite reflectance values (1.87-4.78\% Ro) indicated that the Lokpanta source rock (Late Cenomanian-Early Turonian) is mature to overmature. The vitrinite maturation profiles and the geochemical data suggested the generation of hydrocarbon before the Santonian compressional uplift of the Abakaliki-Benue Trough with its resultant sediment folding, which displaced the depo-centre from the Abakaliki Basin to the Anambra and Afikpo platforms. The subsequent erosion and non-deposition in the Abakaliki Basin raised the Lokpanta Shale above the oil generative window. The renewed sedimentation in the Campanian resulted in sagging due to sediment load creating the Anambra Basin. The lack of an effective trapping mechanism in the pre-Santonian may imply that hydrocarbon generated before the uplift migrated away, probably to upper and/or lower horizons (observed as oil shows in the region); some of which may be contributing to the Niger Delta crude. This is evidenced by the correlation of the Niger Delta deep sea samples to the Cretaceous (Lokpanta Shale) source rock and occurrence of biomarkers of Cretaceous origin (ab-hopanes and oleananes in the Opuama Channel complex, northern depobelt, Niger Delta).

Keywords. 1D basin model; Lokpanta Shale; hydrocarbon maturation; Benue Trough; Anambra Basin. 


\section{Introduction}

Basin modelling is a useful method for investigating the burial history and thermal evolution of sedimentary basins (Guo et al. 2012; Mashhadi et al. 2015). The techniques of basin modelling enable explorationists to simulate basin evolution, petroleum generation, expulsion, migration and accumulation. Regional scale, hydrocarbon charge evaluation usually forms the basis of any exploration risk assessment, and an accurate reconstruction of charge history is crucial for any successful petroleum exploration. Previous studies on the hydrocarbon potential of the southern Benue Trough and the Anambra Basin have established the presence of source rocks with adequate burial history and maturation to generate hydrocarbons in these inland basins (Agagu and Ekweozor 1982; Ekweozor and Gormly 1983; Unomah and Ekweozor 1993; Onuoha and Ekine 1999). The Late Cenomanian to Early Turonian Lokpanta Shale, which is the basal unit of the EzeAku Formation in the Eze-Aku Group, consist of alternating dark grey to black shales, marl and siltstones. The upper sections are mainly alternating sandstones, shales and limestones. This unit is regarded as the key petroleum source rock for the basins.

With renewed interest in the inland sedimentary basins of Nigeria, recent studies have attempted to evaluate the hydrocarbon generative potential of these basins (Anyiam and Onuoha 2014a, b; Oluwajana and Ehinola 2016) with relative sparse one-dimensional (1D) models. Anyiam and Onuoha (2014a,b) modelled the hydrocarbon generation potential of the Eze-Aku Shale in the Amansiodo-1 well using a 1D Genesis Zetaware software. They concluded that hydrocarbon generation started at about 83 Mya (million years ago) at the end of the Santonian, but was terminated consequent upon the tectonic inversion in the southern Benue Trough, and resumed in the Campanian (80 Mya) after reburial and deposition of the Campano-Maastrichtian sediments. However, the hydrocarbon generation potential of the Anambra Basin and Benue Trough is yet to be fully characterised or well understood, at present. The objectives of this work include describing the burial history of the identified source rock, the thermal maturation history of the source rock, the time of generation of the first hydrocarbon, expulsion, migration, trapping, accumulation and its preservation.

\section{Geological framework}

The evolution of the Benue Trough with its sedimentary basins (figure 1) began with the breakup and dispersion of the African and South American plates in the Late Jurassic (Burke et al. 1971). This was initiated by a Y-shaped RRRtriple junction ridge system of which one arm failed to develop, forming an aulacogen - the Benue Trough (Burke et al. 1971; Hoque and Nwajide 1984; Benkhelil 1989). Subsequent wrench movement along rejuvenated basement fault systems resulted in the formation of several basins and sub-basins along the Benue 'aulacogen', each with its own sedimentary fill. The Benue Trough is broadly subdivided into three main geographical regions: the southern, central and northern Benue Trough (Nwajide 2013). The stratigraphic succession in the southern Benue Trough (the study area) displays facies-stacking patterns and are grouped into three mega-tectonic cycles each constrained by the extent of the major basins, namely, the Abakaliki Basin (Neocomian-early Santonian), the Anambra Basin (Campanian-Maastrichtian) and the Tertiary Niger Delta (Murat 1972). The summary of the generalised stratigraphic succession in the region is shown in figure 2 .

There are two identified phases of tectonic uplifts and the associated unconformities in the southern Benue Trough; these are the sub-regional Cenomanian and regional Santonian deformations that fragmented the southern Benue Trough into the Abakaliki anticlinorium and the flanking Anambra Basin (Murat 1972). Before the Santonian, the Benue Trough constituted the platform section of the emerging marine transgression in which shallow marine clastics and carbonates were deposited. During the Santonian event, the axial part of the Benue Trough was uplifted into a major anticlinorium, creating two depressions to the east and west (Benkhelil 1989; Nwajide 2013). These two structural units - Afikpo and Anambra basins, respectively, became the main depositional axis after an intervening period of erosion. Campanian sediments were deposited after the Santonian thermotectonic event. The Maastrichtian deposits, which are cycles/repetitions of alternations of sandstones and shales with coal seams, appear to be the youngest sediments that were deposited before the cessation of major subsidence in the region. Subsequently, the main depositional axis shifted southwards to form the Palaeocene - Recent Niger Delta. The geomorphology of the region 


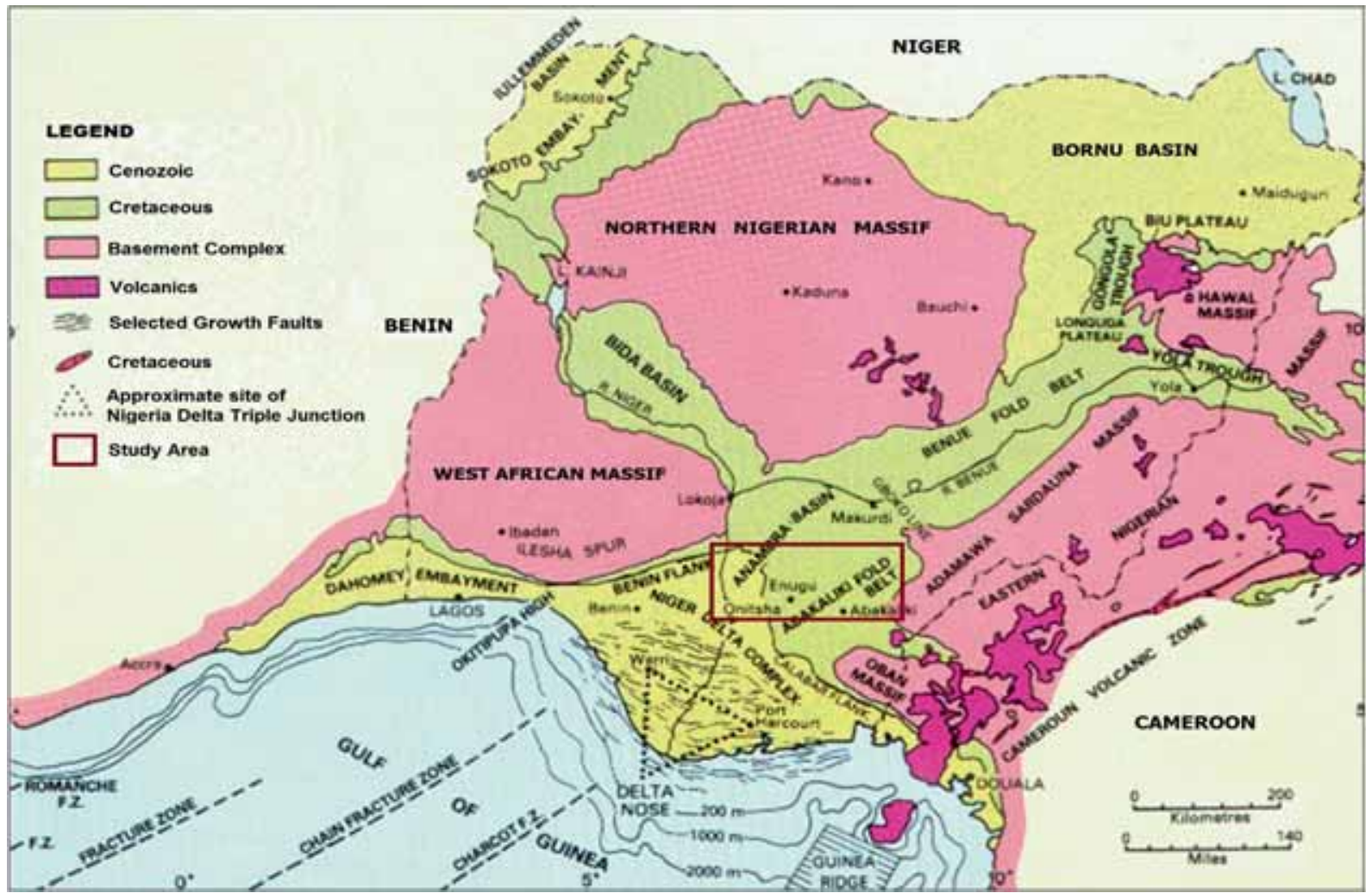

Figure 1. Geological map of Nigeria with main sedimentary basins, selected growth faults in the delta and structural trends (after Whiteman 1982).

shows a juxtaposition of escarpments and hills with low-lying peneplanes in the region, suggesting that thick sections of rock were eroded from the outcropping surfaces subsequent to the cessation of subsidence in the region. The quantitative estimates of the size of the uplifts and/or erosion are yet to be calculated.

\section{Methodology}

Petromod-1D modelling software was used to simulate a reconstruction of the burial (subsidence) history and thermal maturity model of eight exploratory wells (Wells XA-1, XB-1, XC-1, XD1, XE-1, XF-1, XG-11B and XH-1) (figure 3), representing a regional study of the sedimentary basins (Anambra Basin and Benue Trough) of south-eastern Nigeria. This involved modelling and calibration of a single point data, wherein geological and geochemical information are integrated to model the formation and evolution of the basin. Detailed information on total sedimentary composition, burial depths, stratal thicknesses, absolute ages and lithologic composition (by percentage) were determined from well logs, well completion reports, biostratigraphic data and unpublished reports provided by the Shell Petroleum Development Company of Nigeria (SPDC). These were used to develop a conceptual stratigraphic model to reconstruct subsidence and thermal history in the region. The present study adopted the methodology of Hantschel and Kauerauf (2009).

Source rock intervals were identified and appropriate geochemical parameters - kerogen type, total organic carbon, hydrogen index - obtained from published reports (Agagu and Ekweozor 1982; Ekweozor and Gormly 1983; Unomah and Ekweozor 1993) were imputed into the model. The kinetic model of Pepper and Corvi (1995) was used, taking into account the type of kerogen (mixed type II/III). As inputs for calibrating the basin model, thermal maturity (vitrinite reflectance) data for all eight wells were obtained from Unomah and Ekweozor (1993), while corrected bottom-hole temperatures and average geothermal gradients from four of the eight wells are from Onuoha and Ekine (1999). Breaks in vitrinite reflectance values from the vitrinite maturation profiles (Unomah and Ekweozor 1993) were used to estimate erosion and heat flow (HF) changes and computed depth profiles of temperature and vitrinite reflectance 


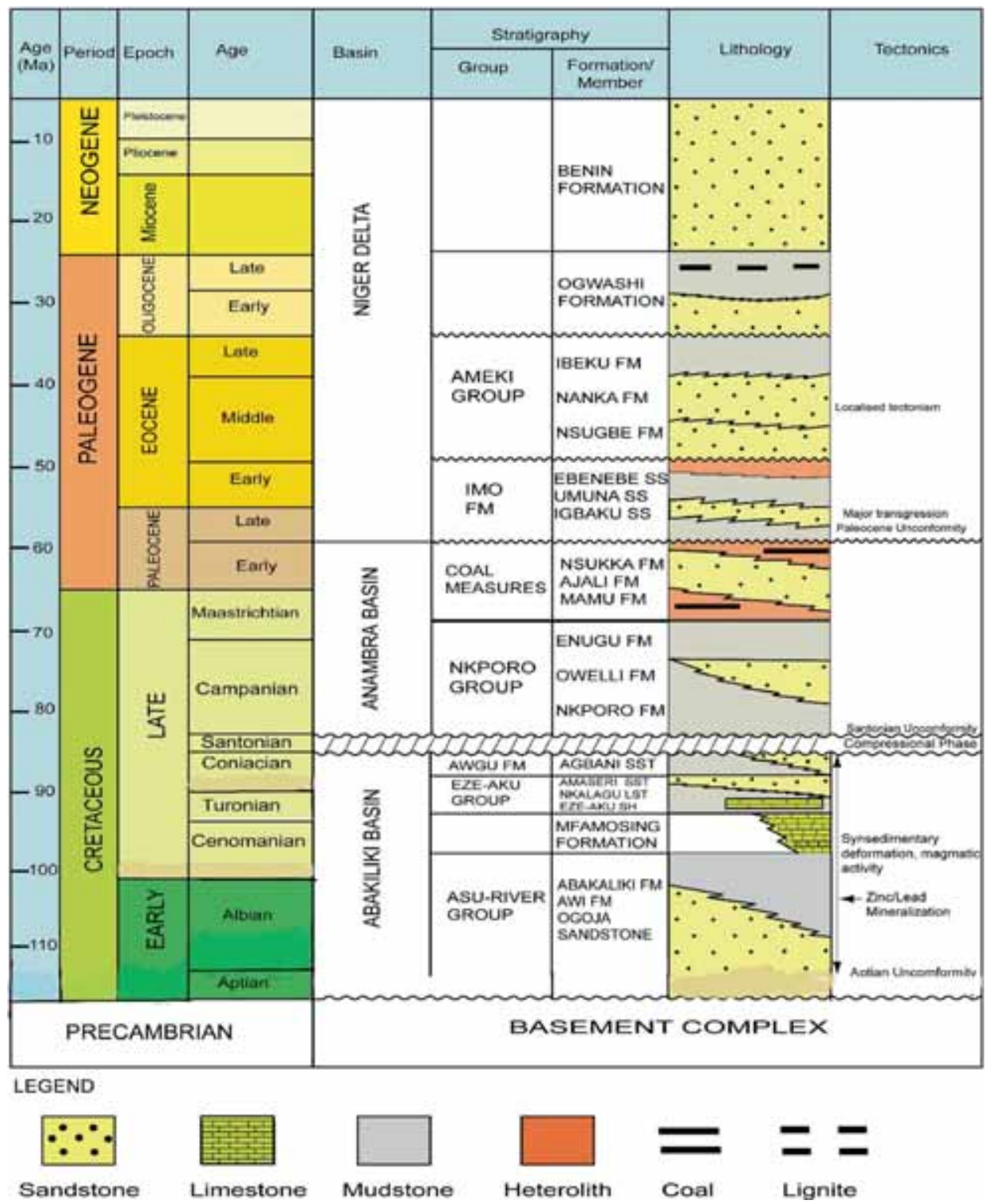

Figure 2. Stratigraphic succession in the south-eastern Nigeria basins (after Nwajide 2005; Ekwenye et al. 2014).

were perturbed until a close match was obtained with measured data. Vitrinite reflectance was modelled using the easy \% Ro method (Sweeney and Burnham 1990).

Boundary conditions that define the thermal evolution of modelled layers through time were assigned to the model. The boundary conditions include palaeo-water depth (PWD, in $\mathrm{m}$ ), an upper thermal boundary or sediment-water interface temperature (SWIT, in ${ }^{\circ} \mathrm{C}$ ), and a lower thermal boundary or basal $\mathrm{HF}$ (in $\mathrm{mW} / \mathrm{m}^{2}$ ). PWD values were estimated from an integrated understanding of the depositional environments of modelled layers, local tectonic subsidence and changes in eustatic sea level. Petromod-1D estimates the SWIT through time, based on the method described by Wygrala (1989). Variable HF values used as input ranged from the presentday $\mathrm{HF}$ value of $48 \mathrm{~mW} / \mathrm{m}^{2}$ (Onuoha and Ekine 1999) to the palaeo-HF value of $75 \mathrm{~mW} / \mathrm{m}^{2}$ that corresponds to the peak period of rifting in the Benue Trough, about 120 Mya (Benkhelil 1989). The modelled HF history was calibrated to get a good fit between simulated and measured vitrinite reflectance data (figure $4 \mathrm{a}-\mathrm{d}$ ).

\section{Results and discussion}

\subsection{Burial (subsidence) history}

The broad tectonic subsidence patterns are the same everywhere in the study area, as shown 


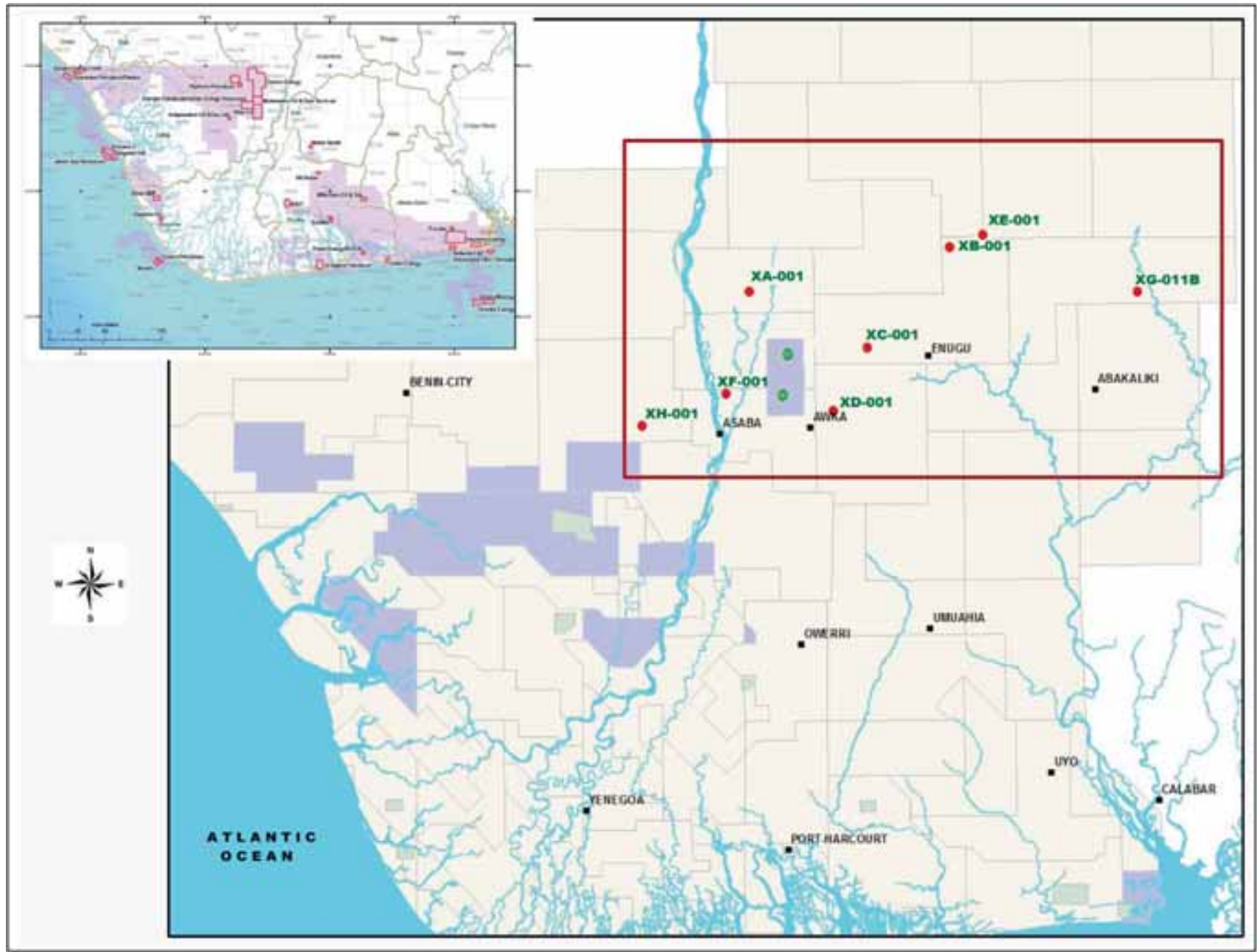

Figure 3. Concession map of southern Nigeria showing the well bore distribution in the study area (within the red box).

by subsidence history plots of the eight wells (figure $5 \mathrm{a}-\mathrm{h}$ and table 1 ). However, the subsidence (sediment accumulation) rate varied widely through geologic time, from Cretaceous to Palaeogene (figure 6 and table 2). The phases of rapid subsidence correspond to the main phase of rifting (Cenomanian-Turonian), and periods of increased sediment supply (Campanian and Maastrichtian) due to rapid erosion and unroofing of the structurally inverted Benue Trough, post-Santonian (Benkhelil 1989; Nwajide 2013). The Late Cenomanian to Early Turonian Lokpanta Shale, which is the unit of interest, has been buried to different depth maxima at the different well locations; the present-day burial depth is usually shallower than the maximum depth of burial encountered, throughout its history (figure $5 \mathrm{a}-\mathrm{h}$ ). This has implications for thermal maturity.

Using the subsidence curve of well XA-1 (figures $5 \mathrm{c}$ and $7 \mathrm{a}$ and $\mathrm{b}$ ), the burial history of the Lower Benue Trough can be subdivided into several tectonic phases, starting with the evolution of the rift basin in the Early Cretaceous and subsequent deposition of about $700 \mathrm{~m}$ thick sediments, followed by a brief period of uplift, non-deposition and erosion at about 94 Mya. Another period of deposition commenced that lasted up to the Santonian, before a regional tectonic event started at about 85 Mya, characterised by structural inversion, regional uplift, widespread magmatism and erosion. Subsequently, deposition and subsidence generally continued until the Palaeogene.

\subsection{Spatial variability in the subsidence history pattern}

The complexity of the Anambra Basin is grossly understated in the literature mainly due to the lack of pervasive tectonic structures on surface outcrops, the rarity of intrusive rocks or volcanoes and the paucity of subsurface data to adequately characterise the complexity of the basin. This apparent 


\section{A. Vitrinite Reflectance, XE - 001}

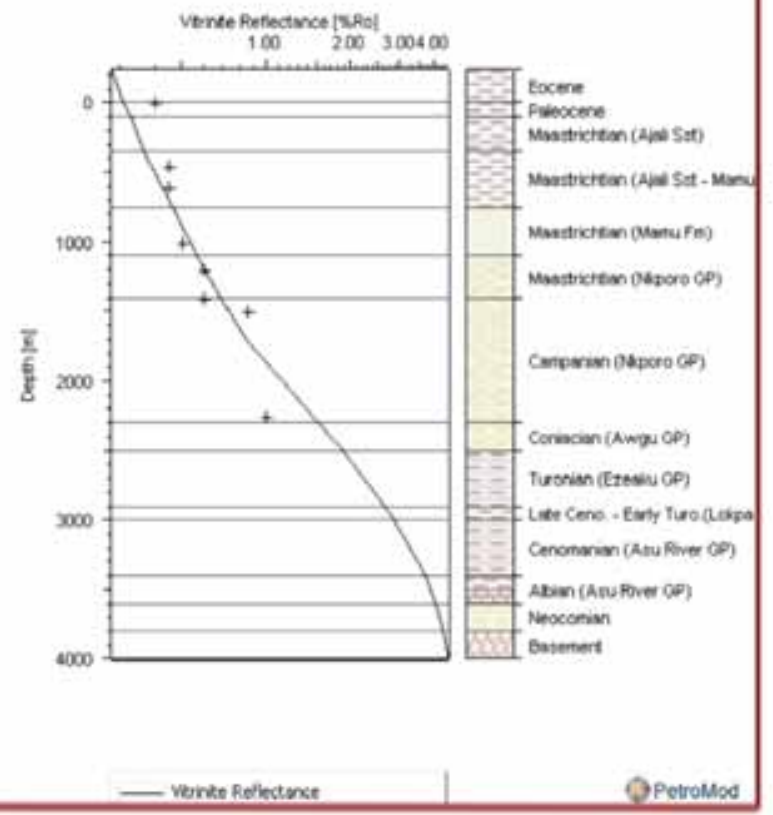

b

\section{Vitrinite Reflectance, XA - 001}

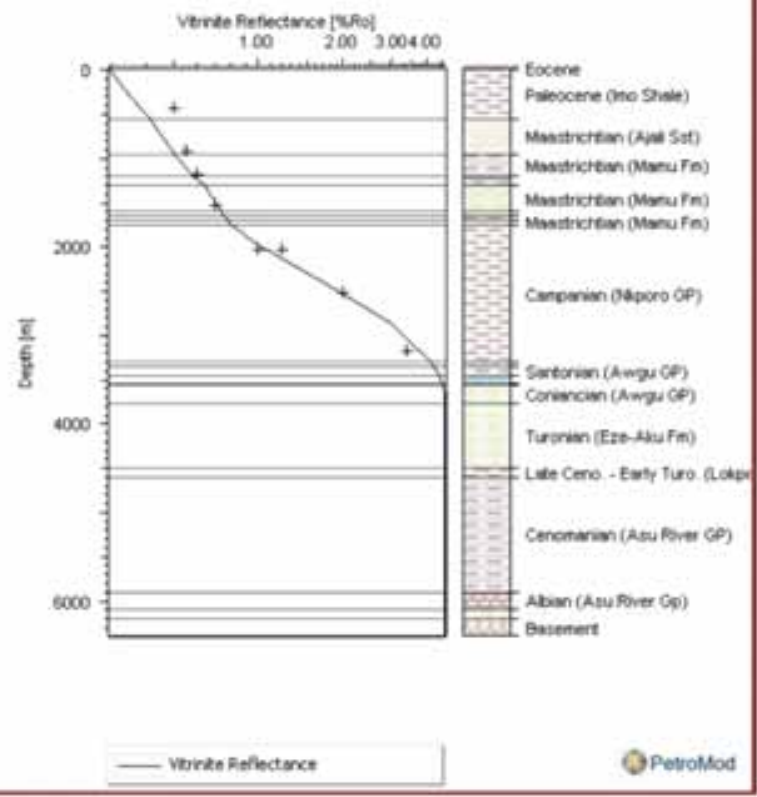

B. Vitrinite Reflectance, XB - 001

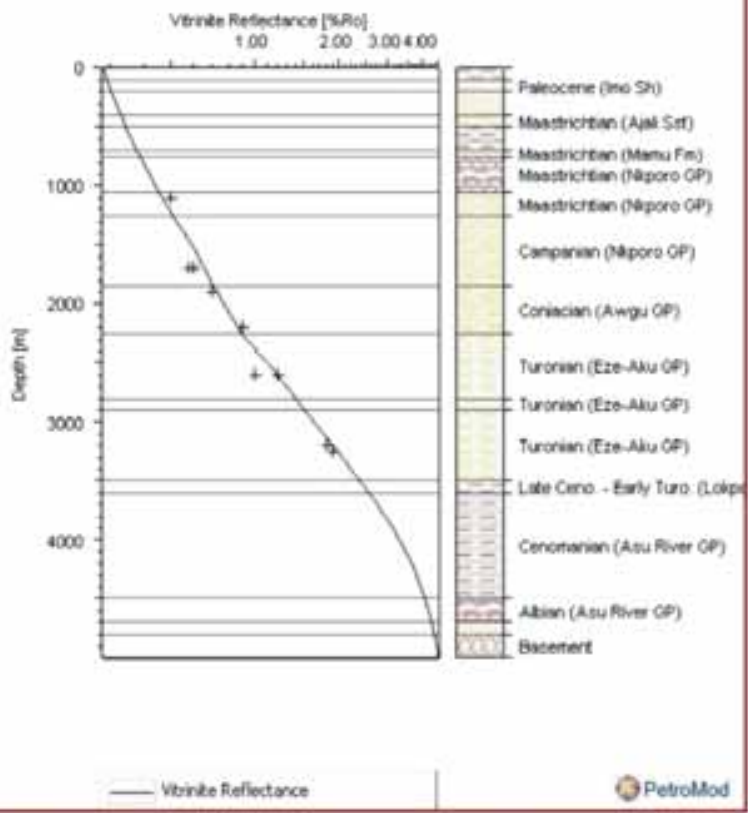

\section{Vitrinite Reflectance, XG - 011B}

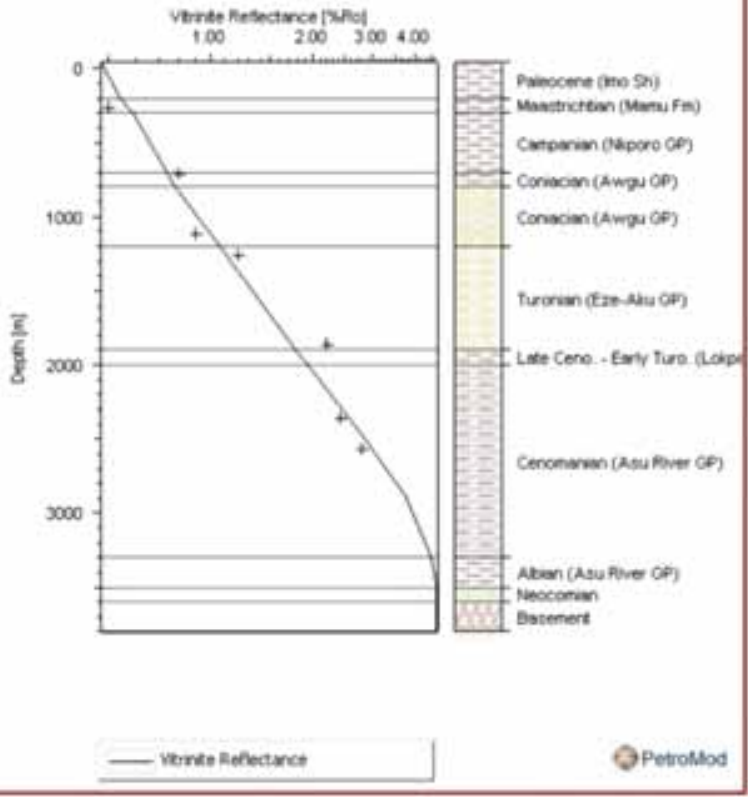

Figure 4. Vitrinite maturation profile for wells: (a) XE-001 and XB-001, (b) XA-001 and XG-011B, (c) XC-001 and XF-001 and (d) XD-001 and XH-001. 
C

\section{E. Vitrinite Reflectance, XC - 001}

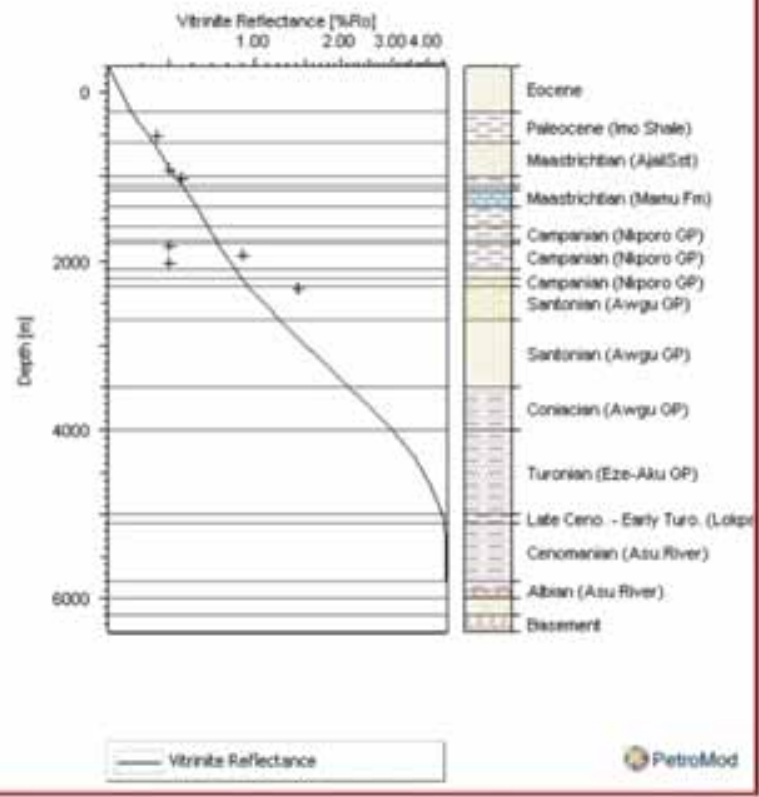

d

\section{G. Vitrinite Reflectance, XD - 001}

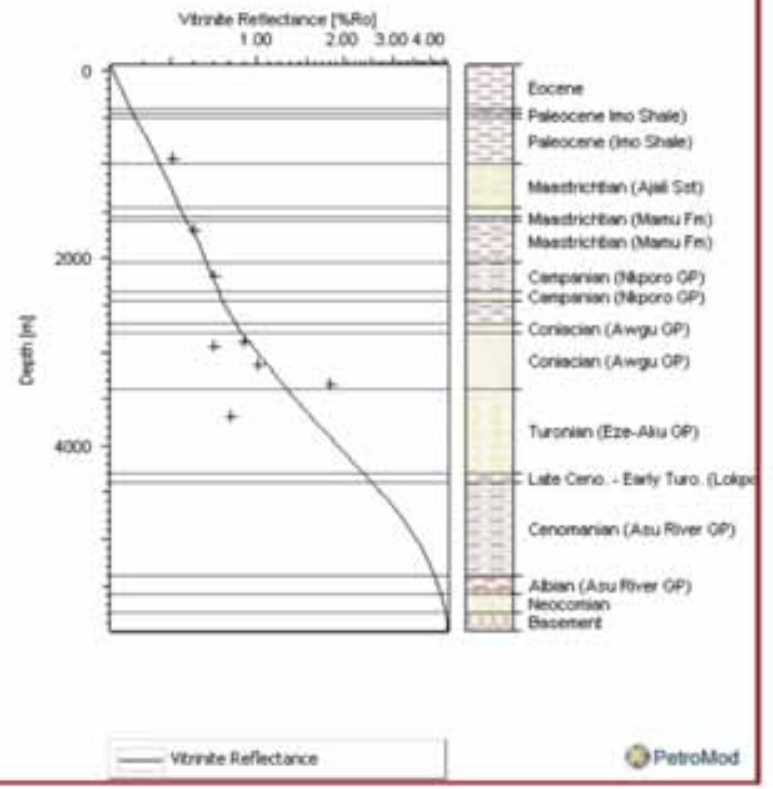

F. Vitrinite Reflectance, XF - 001

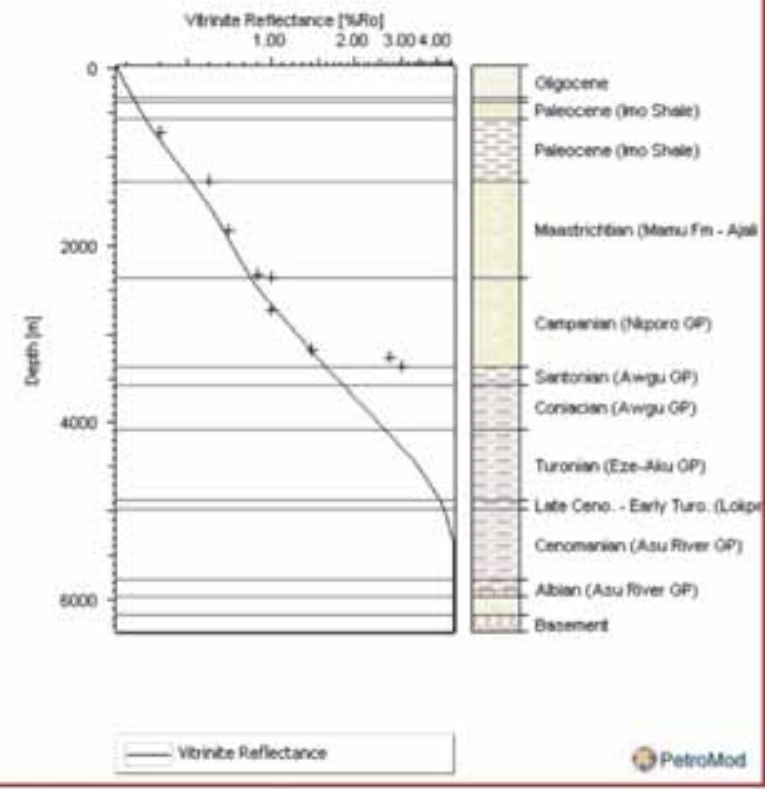

H. Vitrinite Reflectance, $\mathbf{X H}-001$

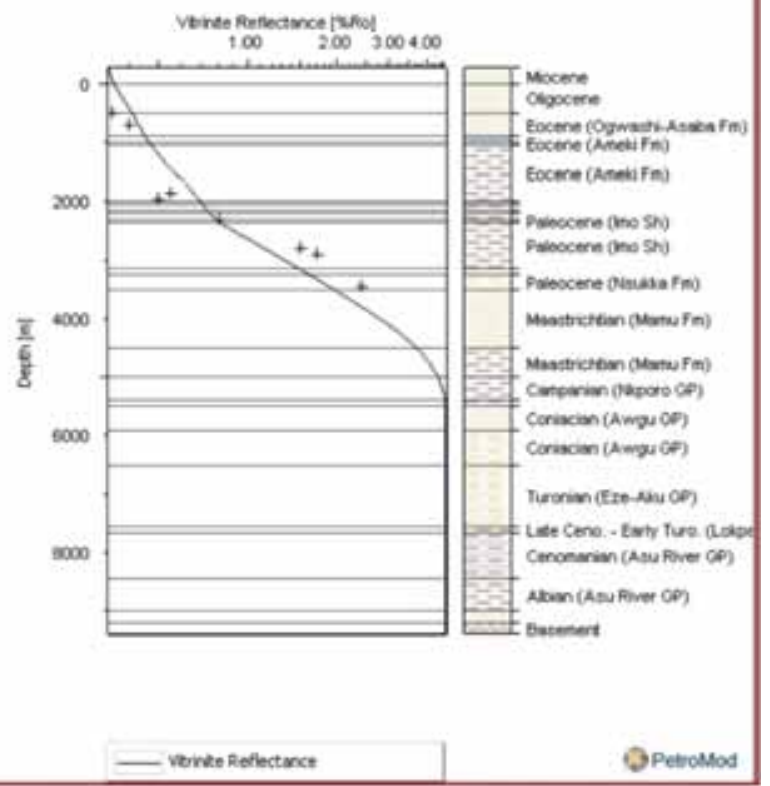

Figure 4. (Continued.)

simplicity was noted by Nwajide (2013), but rare 2D seismic data from the Anambra Basin has shown that it is very complex (figure 8 ). The potential source rock interval of the Cretaceous in the lower Benue Trough has been proven updip in the Anambra Basin, but has never been penetrated in the Niger Delta basin. If seismic reprocessing and new long cable seismic acquisition are applied, 

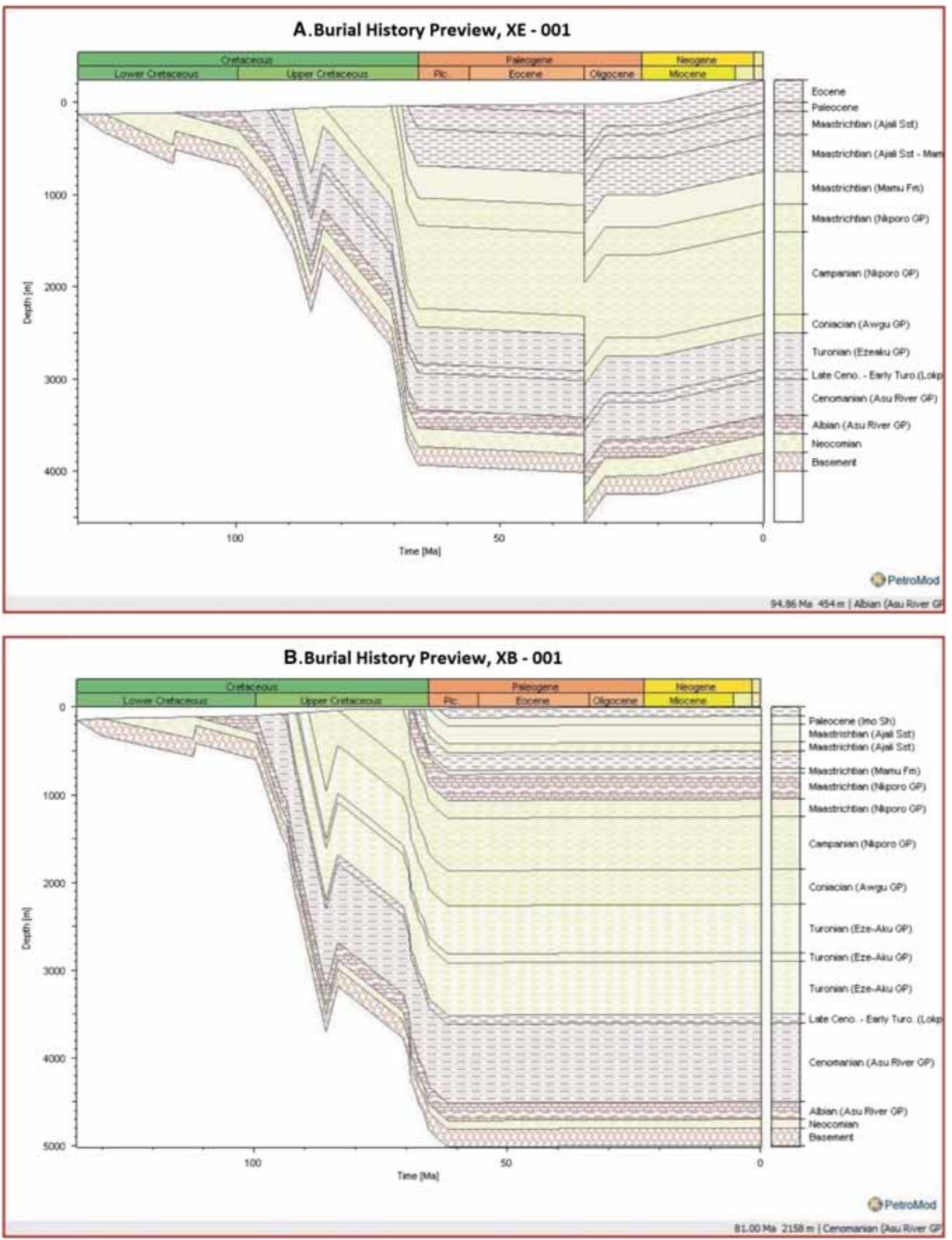

Figure 5. Subsidence history curve for wells: (a) XE-001, (b) XB-001, (c) XA-001, (d) XG-011B, (e) XC-001, (f) XF-001, (g) XD-001 and (h) XH-001. 

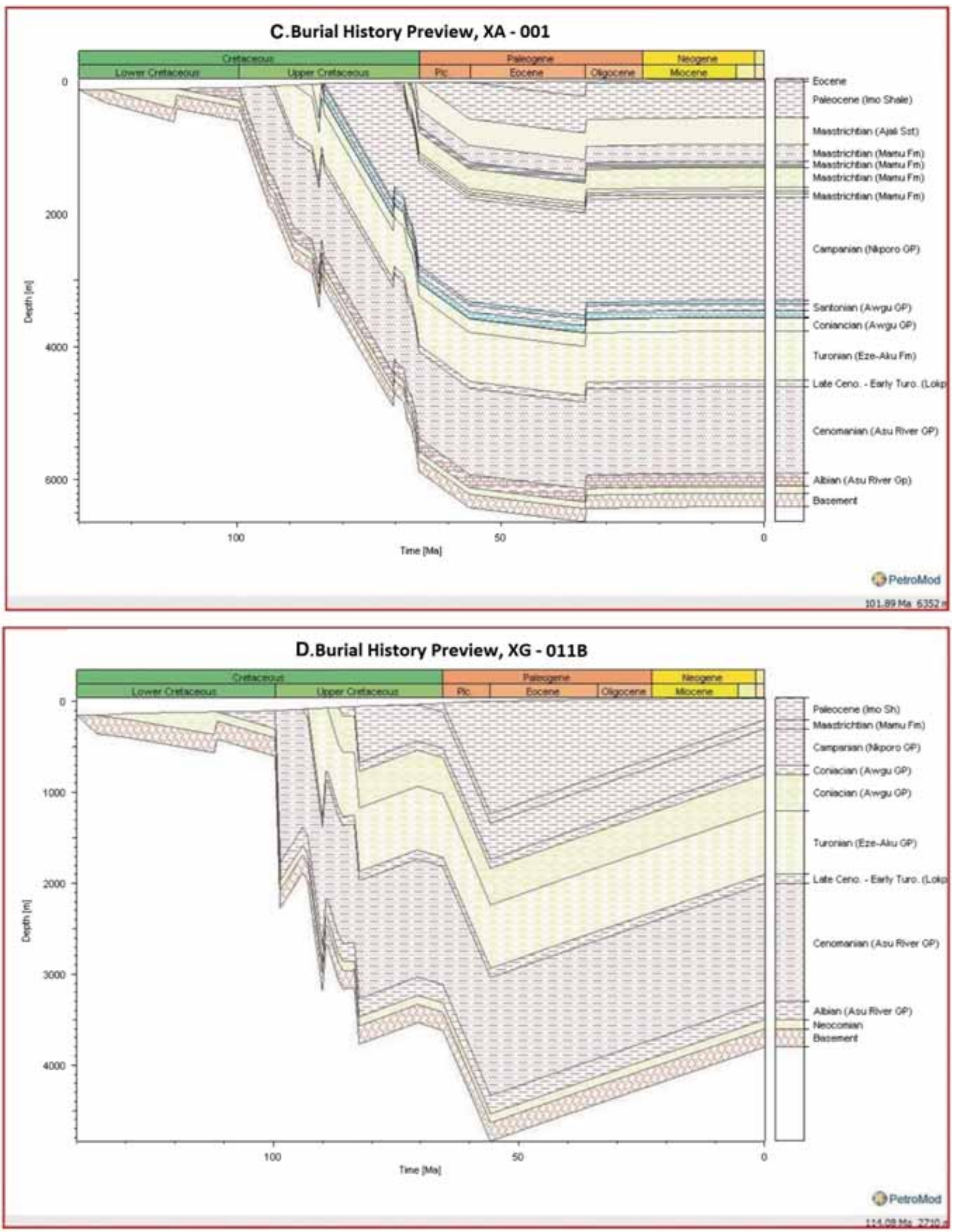

Figure 5. (Continued.) 

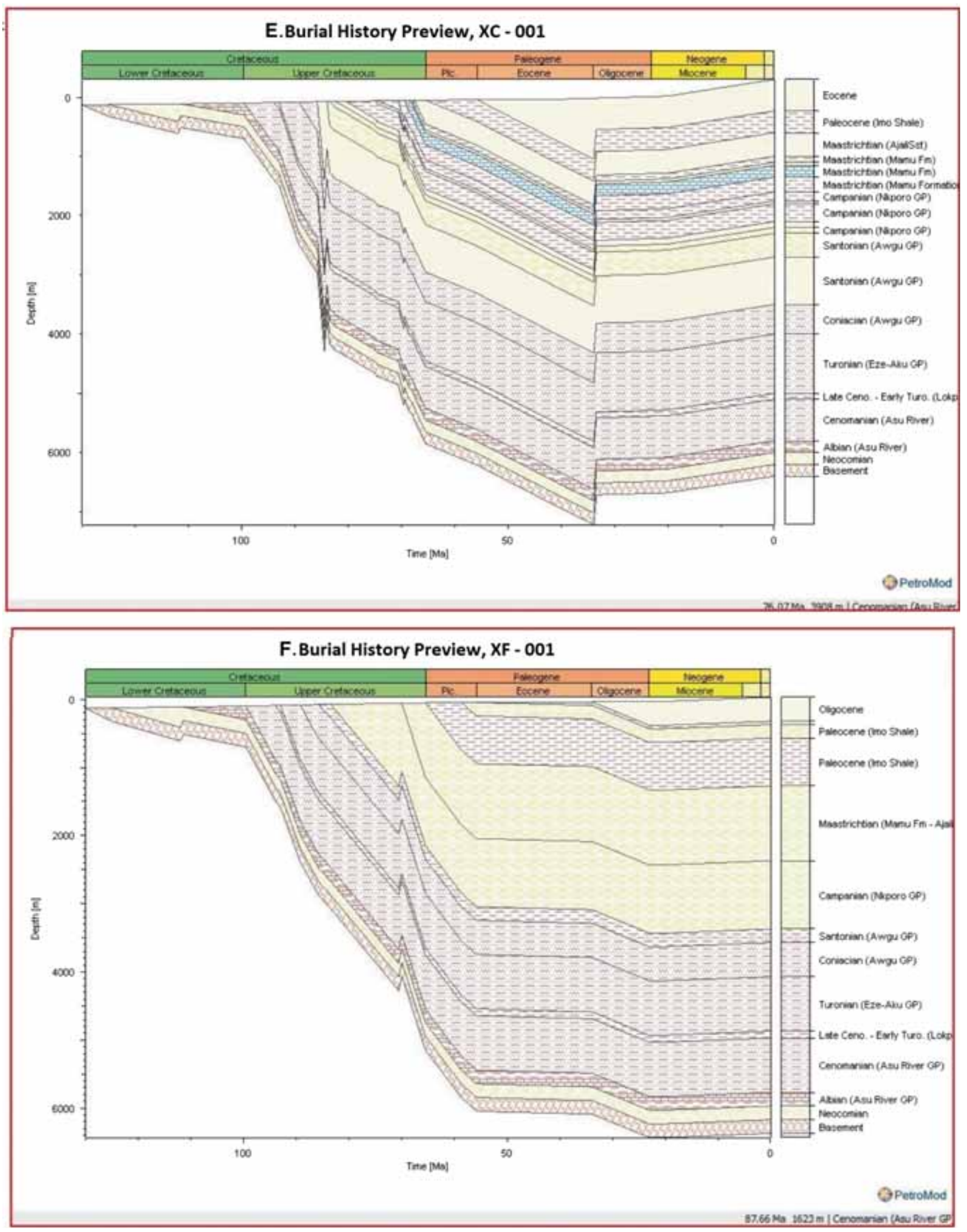

Figure 5. (Continued.) 

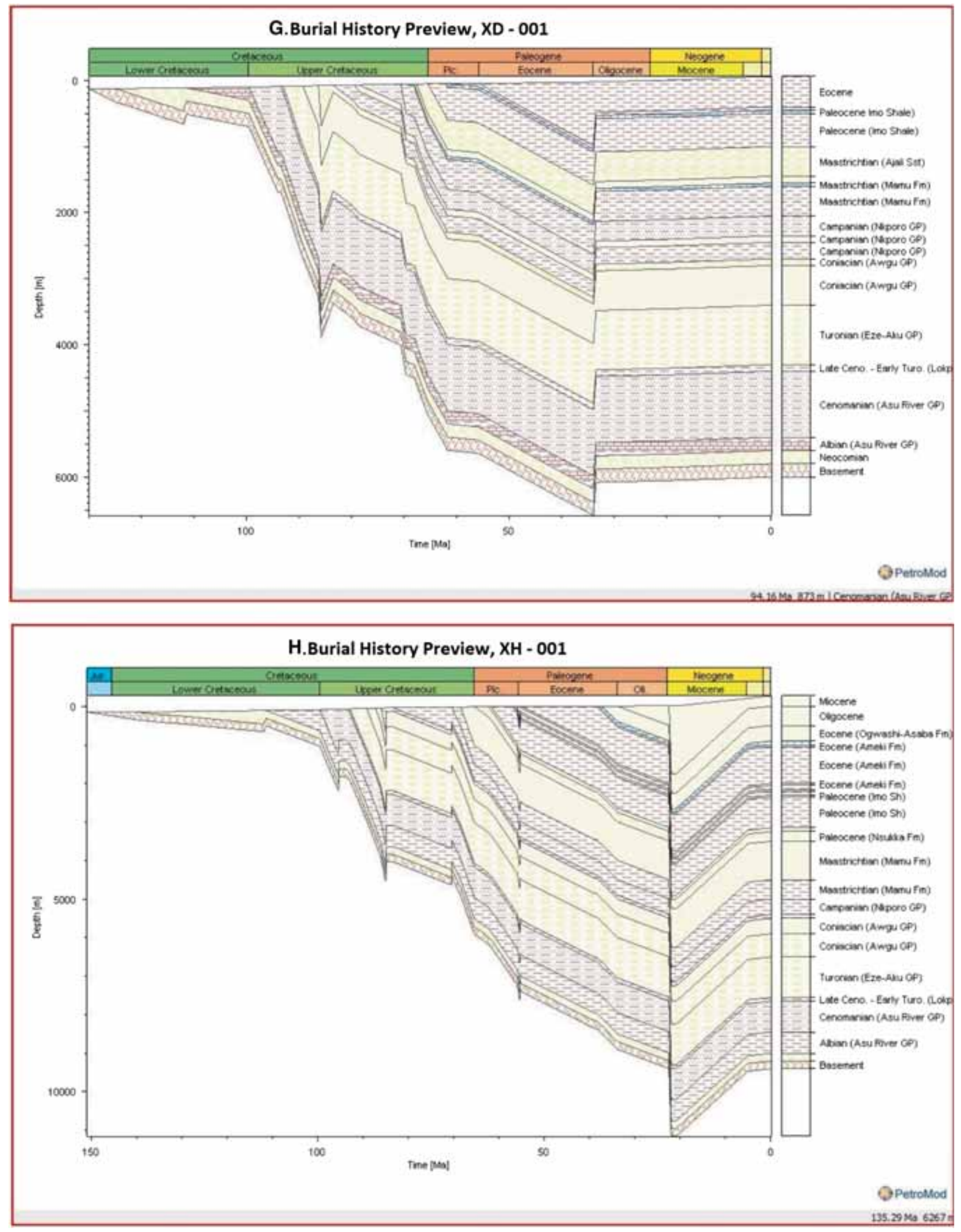

Figure 5. (Continued.) 
Table 1. Estimated subsidence rates across the study area.

\begin{tabular}{llccc}
\hline $\begin{array}{l}\text { Sl. } \\
\text { no. }\end{array}$ & $\begin{array}{c}\text { Well } \\
\text { name }\end{array}$ & $\begin{array}{c}\text { Total sediment } \\
\text { thickness }(\mathrm{m})\end{array}$ & $\begin{array}{c}\text { Age duration } \\
(\text { Mya })\end{array}$ & $\begin{array}{c}\text { Estimated subsidence } \\
\text { rate (m/Mya) }\end{array}$ \\
\hline 1 & XE-1 & 4100 & 130 & 32 \\
2 & XB-1 & 5000 & 135 & 37 \\
3 & XA-1 & 6500 & 130 & 50 \\
4 & XG-11B & 4000 & 140 & 29 \\
5 & XC-1 & 6200 & 130 & 48 \\
6 & XF-1 & 6500 & 130 & 50 \\
7 & XD-1 & 6000 & 130 & 61 \\
8 & XH-1 & 9200 & 150 & 61 \\
\hline
\end{tabular}

these will reduce the uncertainties in imaging the deep structures in the Anambra Basin.

There is no observed trend in the sediment accumulation rates from the basin margin to the centre; this may be due to the structuration and development of 'mini depo-belts' during basin evolution. A simplified stratigraphic correlation of wells within the study area is shown in figure 9 .

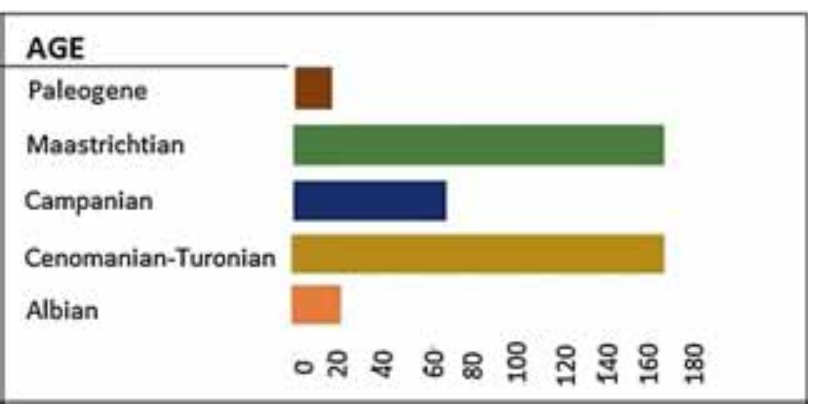

Figure 6. Regional average sediment accumulation rates (m/Mya) through geologic time for the study area.

\subsection{Thermal evolution and timing of hydrocarbon generation}

The vitrinite maturation profiles and the geochemical data confirm Lokpanta Shale as a source rock, deposited during the Late Cenomanian-Early Turonian. The Lokpanta Shale started generating hydrocarbon before the Santonian uplift, which raised the source rock above the oilgenerating window and thereby disrupted the hydrocarbon-generating process. Subsequent reburial, which started with the deposition of the Campano-Maastrichtian sediments, restarted the petroleum-generation process. In addition, the maturation profiles indicate that the source rock has attained present-day vitrinite reflectance values that range from $1.87 \%$ Ro $(1953 \mathrm{~m})$ at XG-1 well to $4.78 \%$ Ro $(4592 \mathrm{~m})$ at XA-1 well (figure $4 \mathrm{~b}$ ). This is indicative of a mature to overmature stage of hydrocarbon source rock. The present depth of burial of this Cretaceous source rock coupled with very high values of vitrinite reflectance and

Table 2. Estimated sediment accumulation rate (in $\mathrm{m} / \mathrm{Mya}$ ) through geologic time.

\begin{tabular}{|c|c|c|c|c|c|c|}
\hline \multirow[b]{2}{*}{$\begin{array}{l}\text { Sl } \\
\text { no. }\end{array}$} & \multirow[b]{2}{*}{$\begin{array}{l}\text { Well } \\
\text { name }\end{array}$} & \multicolumn{5}{|c|}{ Sediment accumulation rates (m/Mya) } \\
\hline & & Albian & $\begin{array}{c}\text { Cenomanian- } \\
\text { Turonian }\end{array}$ & Campanian & Maastrichtian & Palaeogene \\
\hline 1 & XE-1 & 19.2 & 89 & 71.5 & 140 & 4.6 \\
\hline 2 & XB-1 & 18.1 & 183.3 & 91.7 & 170 & 3.1 \\
\hline 3 & XA-1 & 16.7 & 190.9 & 145.5 & 240 & 9.2 \\
\hline 4 & $\mathrm{XG}-11 \mathrm{~B}$ & 18.2 & 190.9 & 30.8 & 20 & 3.9 \\
\hline 5 & $\mathrm{XC}-1$ & 17.8 & 168.8 & 52.9 & 166.7 & 14.3 \\
\hline 6 & $\mathrm{XF}-1$ & 16.7 & 155 & 74.7 & 203.3 & 19.9 \\
\hline 7 & XD-1 & 18.8 & 203.1 & 52.9 & 151.8 & 16.8 \\
\hline 8 & XH-1 & 47.8 & 177 & 35.1 & 254.4 & 58.3 \\
\hline \multicolumn{2}{|c|}{ Average rate } & 21.66 & 169.75 & 69.38 & 168.28 & 16.26 \\
\hline
\end{tabular}

Note: Periods of high subsidence rate are related to rifting (Cenomanian-Turonian) and rapid sediment supply (Campanian-Maastrichtian). 

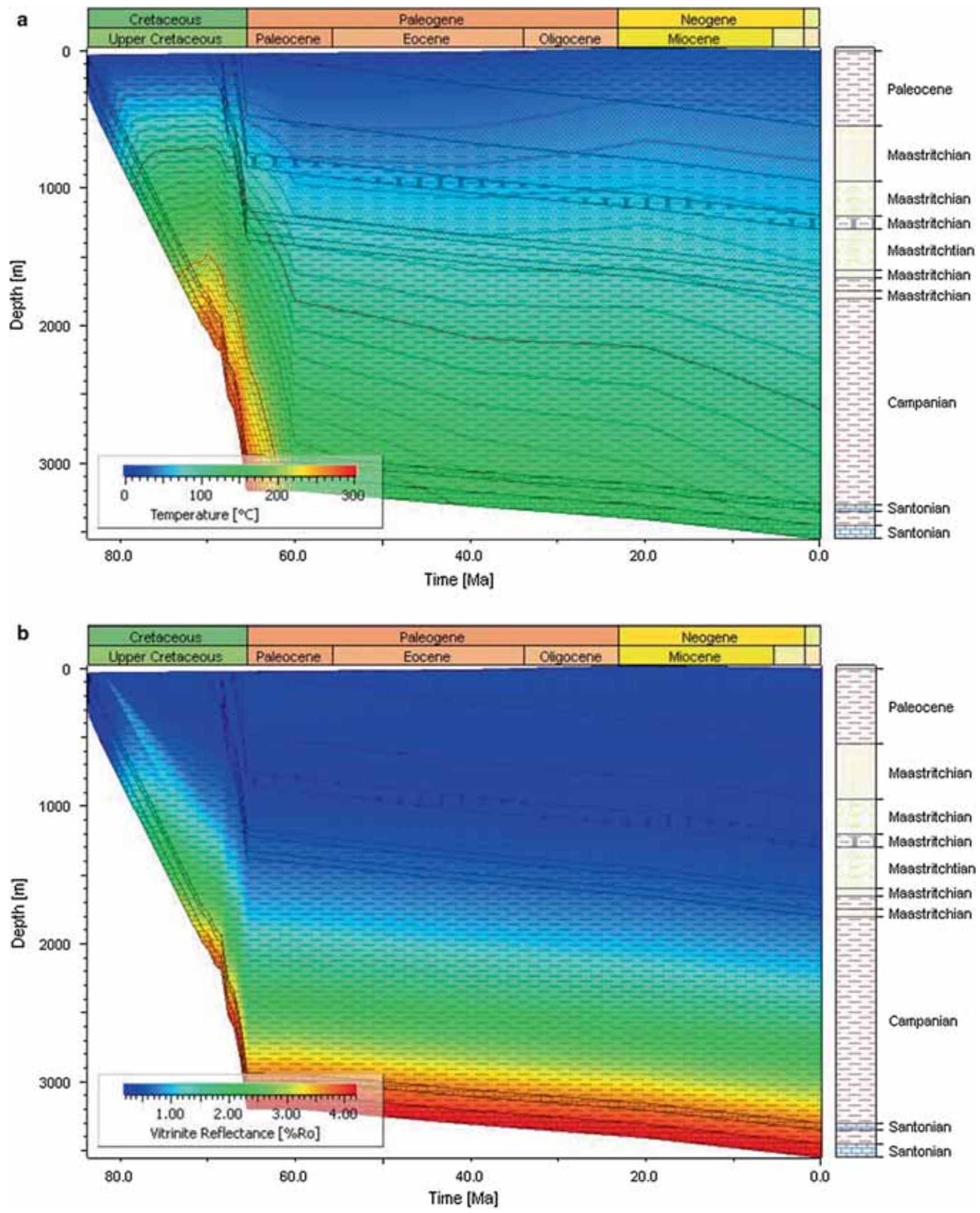

Figure 7. Subsidence curve for well XA-1 with an overlay of (a) temperature and (b) vitrinite reflectance.

geothermal gradient have shifted the hydrocarbon generation phase into a predominance of gas plays found in the southern Benue Trough (figure 10).
The time of generation of the first hydrocarbon was approximately 70 Mya, based on the generated thermal maturity profile for 


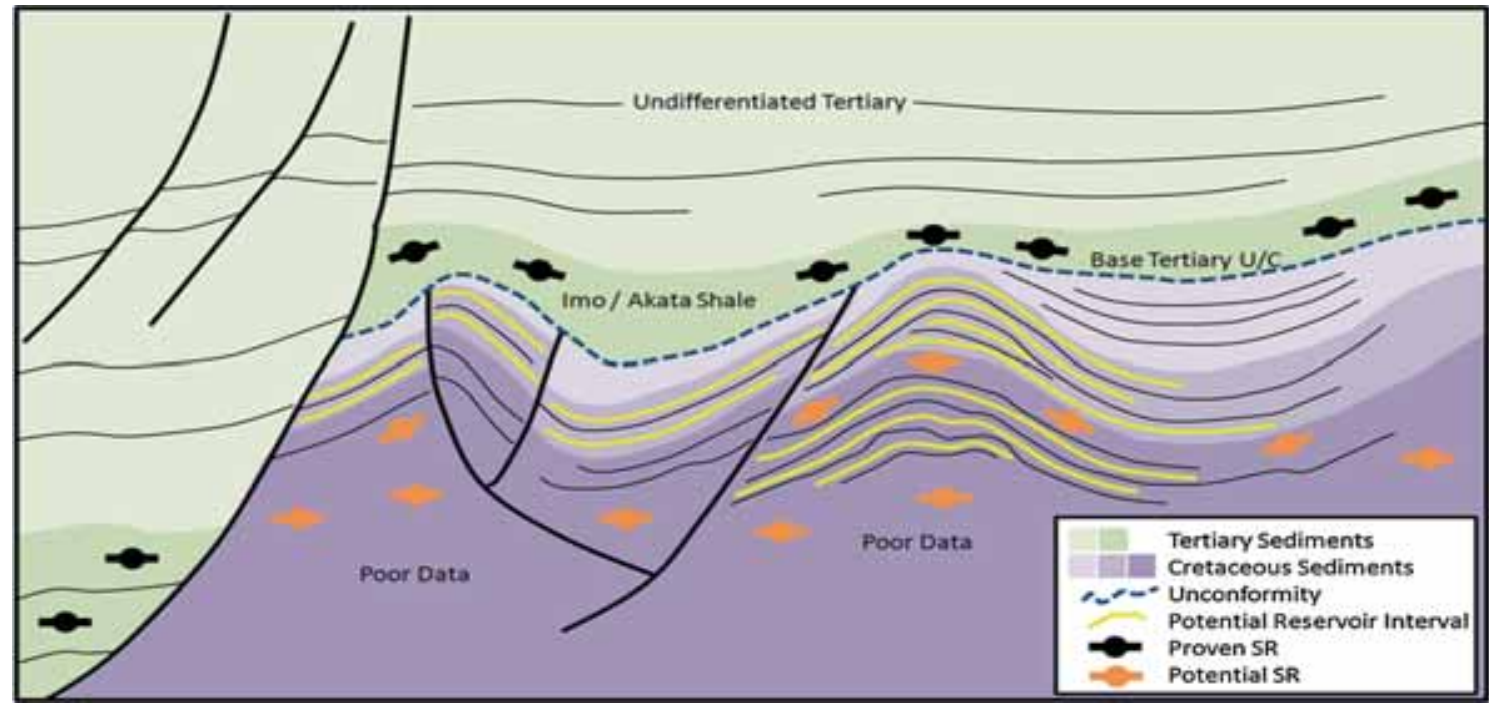

Figure 8. Seismic line of Cretaceous play of the lower Benue Trough (unpublished SPDC report: 2011).

\section{S}

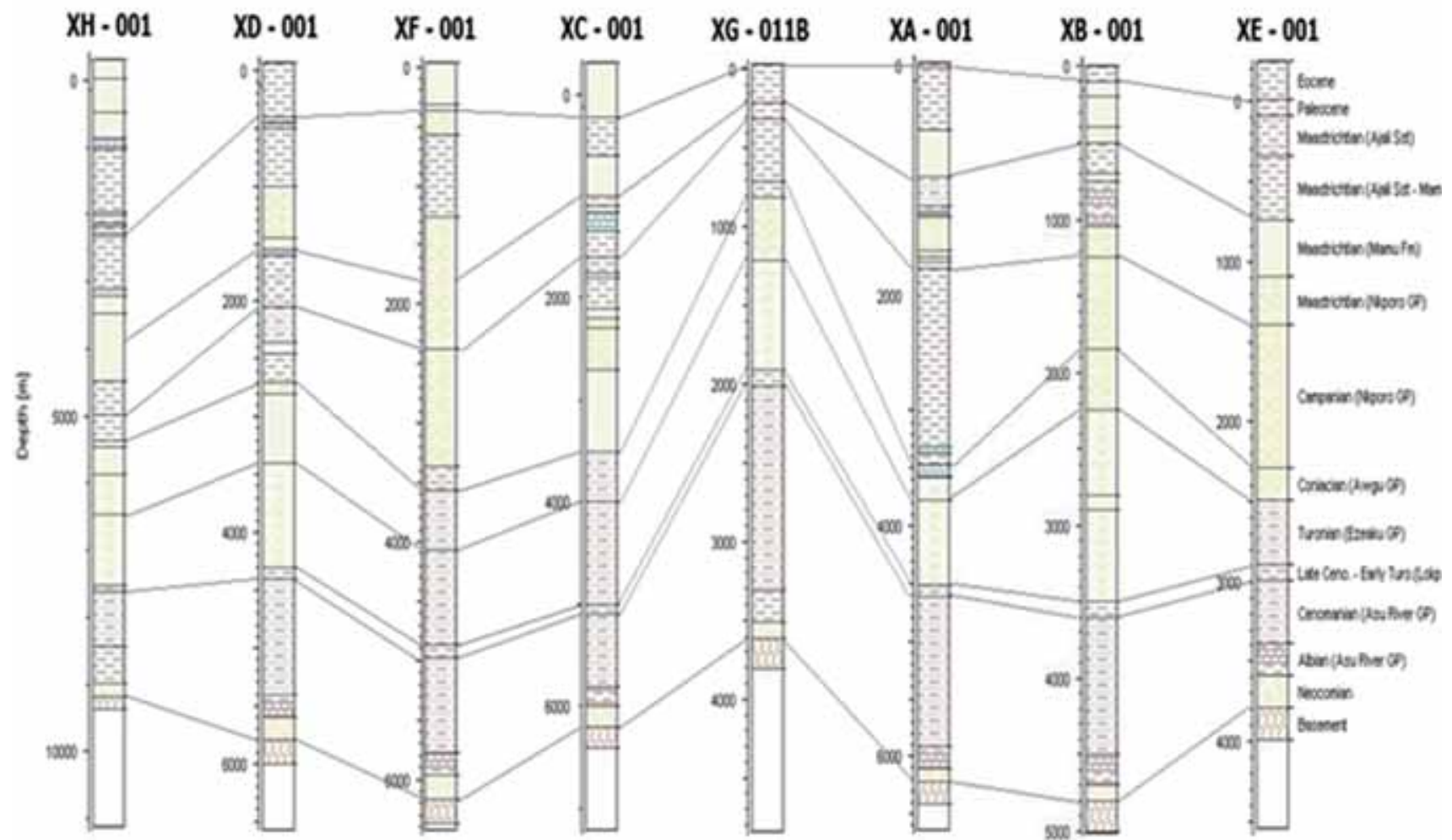

Figure 9. N-S well correlation panel within the study area.

the basin (figure $7 \mathrm{a}$ and $\mathrm{b}$ ). This is very significant for the construction of the event chart from well XC-1 for the petroleum system in this region. The chart indicates that the critical moment was at 70 Mya and is regarded as the final process/element of the petroleum system; this occurred after potential structural traps that may have formed, associated with rifting in the Benue Trough. Subsequently, a stratigraphic trap may have formed by the Owelli sandstone encased in the thick shale formation (Enugu and Nkporo Shale) of the Nkporo Group deposited in the Campanian Anambra Basin (Ekweozor 2006; Nwajide 2013). 


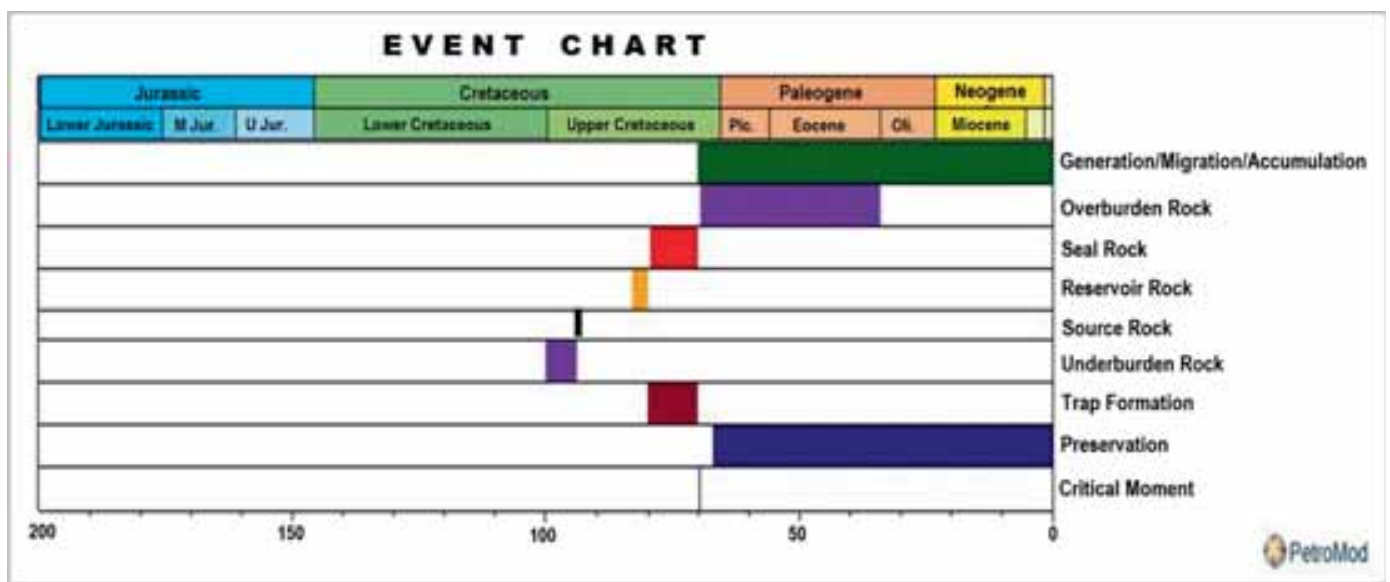

Figure 10. Petroleum systems event chart for well XC-1. This chart is also generally applicable to the basin.
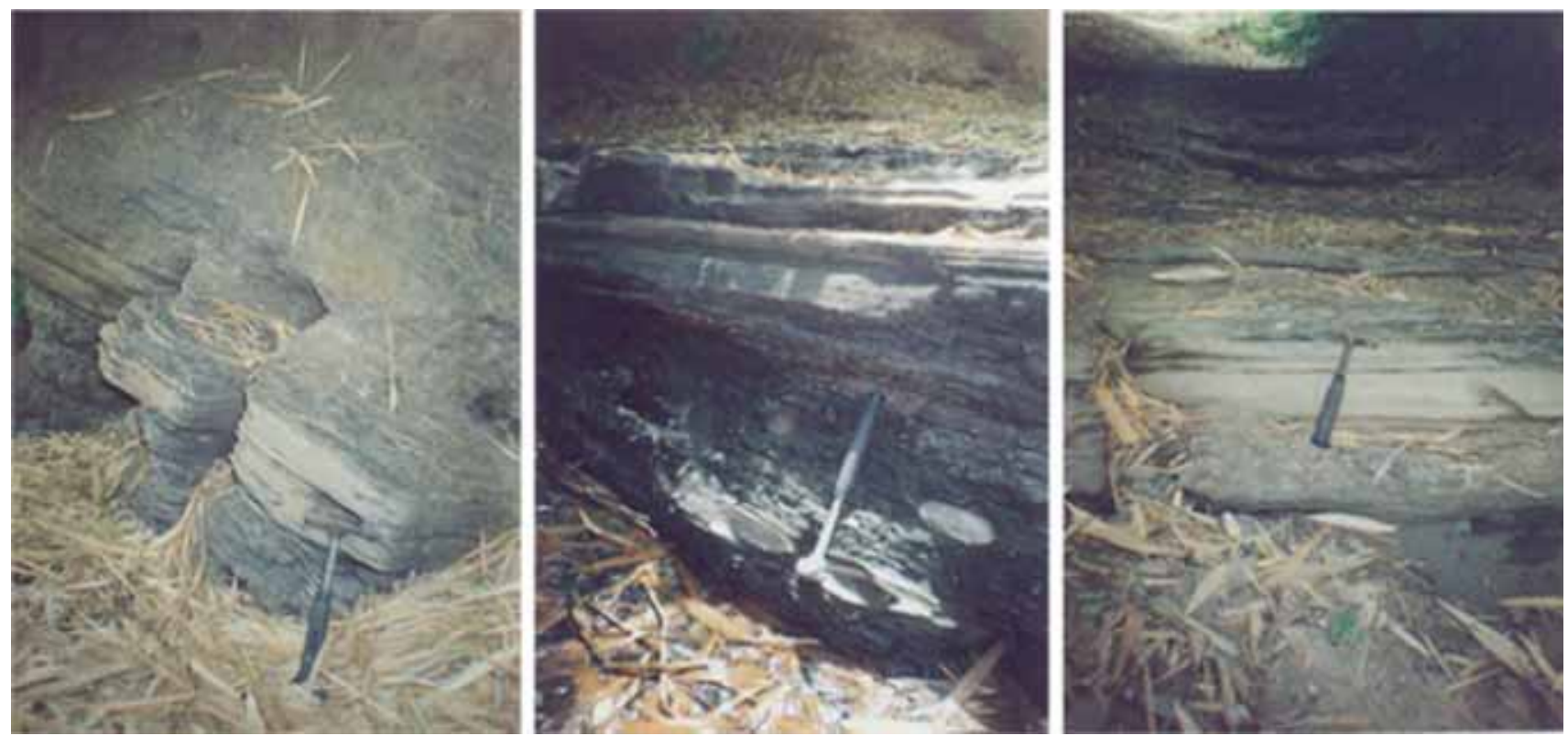

Figure 11. Outcrop photographs of the Lokpanta Shale along the Enugu Port Harcourt expressway, by Onoli-Awgu.

\subsection{Possible contribution of a Cretaceous source to the Niger Delta oil and implications for hydrocarbon prospectivity}

The absence of an effective trapping mechanism (either not formed or breached during structural inversion) in the pre-Campanian period implies that the enormous volumes of crude generated by this Cenomanian-Turonian source rock before the Santonian uplift might have migrated out of this region probably to shallower horizons, part of which may be contributing to the Niger Delta crude (Ekweozor 2006). There are also series of oil shows associated with the Lokpanta Shale exposure in the basin (figure 11); one of such is the oil seepage from the Owelli sandstone of the Nkporo Group at Ugwueme, where the sand is resting unconformably on the folded shales of the Eze-Aku Group (Unomah and Ekweozor 1993; Anyiam and Onuoha 2014a).

The pyrolysis-gas chromatography fingerprints of the deep sea oil sample from the Gulf of Guinea shows a similar distribution with the pyrolysisgas chromatography fingerprints of the onshore oil seep (Ugwueme oil seepage) and the Lokpanta Shale (Ekweozor 2004; Moldowan et al. 2008; Mode et al. 2009). In addition, the similarity of the Vana$\operatorname{dium}(\mathrm{V})+$ Nickel $(\mathrm{Ni})$ ratios for Miocene oils in the Niger Delta with that of Cretaceous crude oil (GeoMark Research, Inc. 1998) provides further 
evidence of the hypothesis of Cretaceous contributions. Significant biomarkers of Cretaceous origin (ab-hopanes and oleananes) are found in Niger Delta crude (Ekweozor et al. 1979a, b; Ekweozor and Udo 1988; Ekweozor and Unomah 1990).

Some previous workers have suggested the probability of a deep Cretaceous source rock contributing to the Niger Delta crude oil (Ekweozor et al. 1979b; Udo and Ekweozor 1990; Frost 1997; Haack et al. 1997; GeoMark Research, Inc. 1998; Ekweozor 2004). This Cretaceous source rock was deposited in the Cenomanian-Turonian period, during the global Cenomanian-Turonian oceanic anoxic event (OAE). The OAE sequestered and preserved large quantities of organic matter along both sides of the Atlantic margin during the midCretaceous (Arthur et al. 1987; Schlanger et al. 1987; Ekweozor and Unomah 1990). These source rocks appear to be responsible for the major oil fields that were discovered on both sides of the Atlantic. For instance, along the West African transform margin is the location of the discoveries in Ghana, Cote D'Ivoire, Liberia, Sierra Leone, Liberia and the Nigerian Aje fields, which are all from Cretaceous targets. Therefore, there may be huge petroleum accumulations from Cretaceous source rocks, somewhere in the Nigerian coast/offshore, probably using the Chain and Charcot fault system as migration conduits. Intensive exploration campaigns may lead to the discovery of more of these Cretaceous oil fields.

\section{Conclusion}

1D basin models of eight wells (figure $5 \mathrm{a}-\mathrm{g}$ ) within the study area, constrained by bottom hole temperature and vitrinite reflectance data (figure $4 \mathrm{a}-\mathrm{e}$ ), suggest that the basin has undergone a relatively complex tectonic history, characterised by phases of rifting followed by thermal subsidence and interspersed with periods of tectonic uplift; the major uplift being the Santonian event. The main phase of rifting was in the Cenomanian-Turonian. This study has identified the Late CenomanianEarly Turonian Lokpanta Shale member of the Eze-Aku Group as one of the main source rocks in the Benue Trough. Hydrocarbon generation within the basin proceeded in two phases, the first phase started before the Santonian, but was disrupted by the Santonian tectonic uplift. Subsequent reburial in the Campano-Maastrichtian period restarted the petroleum generation process.
The study also suggests that the enormous volume of hydrocarbon generated by the source rock may have been migrating through vertical faults, and is responsible for observed oil shows across the basin. It appears that some of the hydrocarbons generated by the Lokpanta Shale might have been trapped within the reservoirs of the Owelli Formation within the Nkporo Group or have migrated into Palaeogene reservoirs of the Niger Delta. This is indicated by the significant presence of biomarkers of Cretaceous origin in the Niger Delta crude oils.

\section{Acknowledgements}

The authors thank the management of the Shell Petroleum Development Company (SPDC), Port Harcourt, Nigeria, for provision of some of the data and software used for this study. Special thanks to Prof C M Ekweozor of the Oil and Gas Academy for his insightful contributions throughout the duration of the research.

\section{References}

Agagu O K and Ekweozor C M 1982 Source-rock characteristics of Senonian Shales in the Anambra Syncline, Nigeria; J. Min. Geol. 19(1) 132-140.

Anyiam O A and Onuoha K M 2014a Hydrocarbon generation potentials of the EzeAku Shale, Southern Benue Trough, Nigeria; Arabian J. Geosci. 7(12) 5431-5441.

Anyiam O A and Onuoha K M 2014b A study of hydrocarbon generation and expulsion of the Nkporo Shales in Anambra Basin, Nigeria; Arabian J. Geosci. 7(9) 37793790 .

Arthur M A, Schlanger S T and Jenkyns H C 1987 The Cenomanian-Turonian oceanic anoxic event, II. Palaeoceanographic controls on organic-matter production and preservation; Geol. Soc. London, Spec. Publ. 26(1) 401420.

Benkhelil J 1989 The origin and evolution of the Cretaceous Benue Trough, Nigeria; J. Afr. Earth Sci. 8 251-282.

Burke K C, Dessauvagie T F J and Whiteman A J 1971 Opening of the Gulf of Guinea and geological history of the Benue depression and Niger Delta; Nat. Phys. Sci. 233 51-55.

Ekwenye O C, Nichols G J, Collinson M, Nwajide S C and Obi G C 2014 A paleogeographic model for the sandstone members of the Imo Shale, Southeastern Nigeria; J. Afr. Earth Sci. 96 190-211.

Ekweozor C M 2004 Insight into origin of giant hydrocarbon fields of deep/ultra-deep offshore Niger Delta from geochemistry of cretaceous carbonaceous sediments from Southern Nigeria; In: Abstract volume, 6th international conference on petroleum geochemistry $\&$ exploration in the Afro-Asian region, Beijing, China, pp. 25-26. 
Ekweozor C M 2006 Searching for petroleum in the Anambra basin, Nigeria; In: Hydrocarbon potentials of the Anambra basin: Geology, geochemistry and geohistory perspectives: Proceedings of PTDF seminar 1 (ed.) Okogbue C O, UNN, pp. 83-110.

Ekweozor C M and Gormly J R 1983 Petroleum geochemistry of late cretaceous and early tertiary shales penetrated by Akukwa-2 well in the Anambra Basin, Southern Nigeria; J. Pet. Geol. 6 207-216.

Ekweozor C M and Udo O T 1988 The oleananes: Origin, maturation and limits of occurrence in Southern Nigerian sedimentary basins; Org. Geochem. 13 131-140.

Ekweozor C M and Unomah G I 1990 First discovery of oil shale, in the Benue Trough, Nigeria; Fuel 69 502-508.

Ekweozor C M, Okogun J I, Ekong D E U and Maxwell J R 1979a Preliminary organic geochemical studies of samples from the Niger Delta, Nigeria. I. Analysis of crude oils for triterpanes; Chem. Geol. 27 11-28.

Ekweozor C M, Okogun J I, Ekong D E U and Maxwell J R 1979b Preliminary organic geochemical studies of samples from the Niger Delta, Nigeria. II. Analysis of shale for triterpenoid derivatives; Chem. Geol. 27 29-37.

Frost B R 1997 Cretaceous Niger Delta petroleum; In: Extended abstracts, AAPG/ABGP Hedberg research symposium, petroleum systems of the South Atlantic margin, 16-19 November 1997, Rio de Janeiro, Brazil.

GeoMark Research, Inc. 1998 OILS: Oil information library system, Version 1.0; Houston, Texas.

Guo X, Liu K, He S, Song G, Wang Y, Hao X and Wang B 2012 Petroleum generation and charge history of the northern Dongying depression, Bohai Bay Basin, China: Insight from integrated fluid inclusion analysis and basin modelling; Mar. Pet. Geol. 32(1) 21-35.

Haack R C, Sundararaman P and Dahl J 1997 Niger Delta petroleum system; In: Extended abstracts, AAPG/ABGP Hedberg research symposium, petroleum systems of the South Atlantic margin, 16-19 November 1997, Rio de Janeiro, Brazil.

Hantschel T and Kauerauf A I 2009 Fundamentals of basin and petroleum systems modeling; Springer Science \& Business Media, Berlin, 485p.

Hoque M and Nwajide C S 1984 Tectono-sedimentological evolution of an enlongate intracratonic basin (aulacogen): The case of the Benue Trough of Nigeria; J. Min. Geol. 21 19-26.

Mashhadi Z S, Rabbani A R and Kamali M R 2015 Geochemical characteristics and hydrocarbon generation modeling of the Kazhdumi (Early Cretaceous), Gurpi (Late Cretaceous) and Pabdeh (Paleogene) formations, Iranian sector of the Persian Gulf; Mar. Pet. Geol. 66 978-997.

Mode A W, Ekweozor C M and Mamah C U 2009 Origin of deep sea oils in the Gulf of Guinea; In: Abstracts, NAPE international conference, shelf to deepwater exploration: Shifting paradigm, 29 November-3 December 2009, Abuja, Nigeria.

Moldowan J M, Ekweozor C M, Mamah C, Donyinah S $\mathrm{K}$ and Fago F J 2008 A possible deep source for Niger Delta petroleum; In: Proceedings association of AfroAsian petroleum geochemists.

Murat R C 1972 Stratigraphy and palaeogeography of the cretaceous and lower tertiary in Southern Nigeria; In: African geology (eds) Dessauvagie F J and Whiteman A J, University of Ibadan Press, Ibadan, pp. 251-266.

Nwajide C S 2005 Anambra Basin of Nigeria: Synoptic basin analysis as a basis for evaluating its hydrocarbon prospectivity; In: Hydrocarbon potentials of Anambra Basin: Geology, geochemistry and geohistory perspectives. Proceedings of the PTDF chair in geology (ed.) Okogbue C O, University of Nigeria, Nsukka, Vol. 1, pp. $1-46$.

Nwajide C S 2013 Geology of Nigeria's sedimentary basins; CSS Bookshops Ltd, Lagos, 565p.

Oluwajana O A and Ehinola O A 2016 Hydrocarbon-charge modelling of Anambra Basin, southeastern Nigeria: Implications for cretaceous-sourced plays; Arabian J. Geosci. 9(3) $1-16$.

Onuoha K M and Ekine A S 1999 Subsurface temperature variations and heat flow in the Anambra Basin, Nigeria; J. Afr. Earth Sci. 28(3) 641-652.

Pepper A S and Corvi P J 1995 Simple kinetic models of petroleum formation. Part I: Oil and gas generation from kerogen; Mar. Pet. Geol. 12(3) 291-319.

Schlanger S O, Arthur M A, Jenkyns H C and Scholle P A 1987 The Cenomanian-Turonian oceanic anoxic event, I. Stratigraphy and distribution of organic carbon-rich beds and the marine $\delta^{13} \mathrm{C}$ excursion; Geol. Soc. London, Spec. Publ. 26(1) 371-399.

Sweeney J J and Burnham A K 1990 Evaluation of a simple model of vitrinite reflectance based on chemical kinetics (1); AAPG Bull. 74(10) 1559-1570.

Udo O T and Ekweozor C M 1990 Significance of oleanane occurrence in shales of Opuama channel complex, Niger Delta; Energy Fuels 4 248-254.

Unomah G I and Ekweozor C M 1993 Application of vitrinite reflectance in reconstruction of tectonic features in Anambra Basin, Nigeria: Implication for petroleum potential; Am. Assoc. Pet. Geol. Bull. 77 436-451.

Whiteman A 1982 Nigeria: Its petroleum geology, resources and potentials; Graham and Trotman Ltd., London, Vol. 2, 394p.

Wygrala B 1989 Integrated study of an oil field in the southern Po basin; northern Italy (No. FZJ-2014-03033), Publikationen vor 2000. 